\title{
Essential Oil Composition and Anti-Inflammatory Activity of Salvia officinalis L (Lamiaceae) in Murin Macrophages
}

\author{
Alev Tosun ${ }^{1 *}$, Salman Khan ${ }^{2}$, Yeong Shik Kim², Ángel Calín-Sánchez ${ }^{3}$, \\ Xhevit Hysenaj ${ }^{4}$ and Ángel Antonio Carbonell-Barrachina ${ }^{3}$ \\ ${ }^{1}$ Ankara University, Faculty of Pharmacy, Department of Pharmacognosy, 06100, Tandoğan, Ankara, Turkey, ${ }^{2}$ Natural Product \\ Research Institute, College of Pharmacy, Seoul National University, Seoul, 151-742, South Korea, ${ }^{3}$ Departamento Tecnología \\ Agroalimentaria, Universidad Miguel Hernández de Elche, Carretera de Beniel, 03312 Orihuela, Alicante, Spain, ${ }^{4}$ Xherdo Ltd., \\ Medicinal Plants and Essential Oils, Nikolla Lena, No.138, Tirana, Albania
}

*For correspondence: Email: pharmacogalev@gmail.com; Tel: +90 31220330 89; Fax: +90 3122131081

\begin{abstract}
Purpose: Sage, Salvia officinalis L (Lamiaceae), is widely cultivated medicinal plant for its economic importance and large content of bioactive components; therefore, in the present study, the active components (volatile compounds) and the anti-inflammatory effect of $S$. officinalis have been investigated.

Methods: Salvia officinalis samples were collected from northern and southern Albania, respectively. The crushed leaves were subjected to hydro-distillation, and the essential oils analyzed by gas chromatography GC/FID (for quantification of volatiles) and gas chromatography/mass spectroscopy (GC/MS) for identification.

Results: $\alpha$-Thujone (30.7\%), camphor (26.6\%) and 1, 8-cineole (14.7\%) were the major components of the oil from northern Albania, while camphor (43.8\%), a-thujone (15.9\%), camphene (8.5\%) and 1,8 -cineole $(8.4 \%)$ were the predominant compounds in the sample from southern Albania. The results of the anti-inflammatory tests on these essential oils using murine macrophages indicate that both oils significantly $(p<0.05)$ reduced nitric oxide (NO), and nuclear kappa B (NF-KB) production in RAW 264.7 cells.

Conclusion: The results indicate that NO and NF-KB production in RAW 264.7 cells are greatly decreased by the essential oil of Albanian sage. Thus, the biological properties of sage oil can be attributed to the components of the oil.
\end{abstract}

Keywords: Salvia officinalis, Sage oil, Camphor, Camphene, Lamiaceae, Cineole, Nuclear kappa B, Nitric oxide, $\alpha$-Thujone, Volatile compound

\begin{abstract}
Tropical Journal of Pharmaceutical Research is indexed by Science Citation Index (SciSearch), Scopus, International Pharmaceutical Abstract, Chemical Abstracts, Embase, Index Copernicus, EBSCO, African Index Medicus, JournalSeek, Journal Citation Reports/Science Edition, Directory of Open Access Journals (DOAJ), African Journal Online, Bioline International, Open-J-Gate and Pharmacy Abstracts
\end{abstract}

\section{INTRODUCTION}

Salvia $\mathrm{L}$ is the largest genus of Lamiaceae (previously Labiatae) family; it is spread throughout the world, and some species are economically important because they are used as spices in food industry and flavoring agent in cosmetic industry and aromatherapy. Sage has been most commonly known as aromatic and medicinal plant native from Mediterranean countries, which is extensively cultivated due to its economic importance. Additionally, the essential oil and infusion of Salvia officinalis leaves have also been widely applied in traditional medicine. In this way and since ancient times, the crude herbal extracts of aromatic plants, including sage, have been used 
for different purposes, such as foods, drugs and perfumery [1].

The leaves of sage are very popular for their antioxidative properties, and have been used in the food Industry and in medicine to improve human health. In traditional medicine, the plant has been used for various purposes such as antiinflammatory, antioxidant and treatment of gastric disorders. Moreover, sage ethanol tinctures and decoctions have long been used against inflammations of oral cavity, digestive and intestinal tracts, in gastritis and tonsillitis $[2,3]$. Several other important biological activities of this species such as anti-bacterial, fungistatic, virustatic, astringent, hypoglycemic, eupeptic, anti-hydrotic and cytotoxic have also been reported [4-6].

Diverse phytochemical investigations have been performed to identify biologically active compounds responsible for the therapeutic effects of sage [6]. Consequently, various medicinally important bioactive compounds such as diterpenoids, triterpenoids, flavonoids, polysaccharides, phenolic glycosides and phenolic acid derivatives have been isolated from different species of Salvia [5,7,8]. For example, Raal et al reported that the main compounds of sage oil from Estonia and other European countries were: 1,8-cineole, camphor, $\alpha$-thujone, $\beta$-thujone, borneol and viridiflorol [9].

This study focused on the investigation of the anti-inflammatory activity of the leaves of sage in terms of LPS-stimulated macrophages. The antiinflammatory activity of the Salvia officinalis has been evaluated according to their constituents and their amounts in the essential oils of the species collected from two different regions of Albania (Northern and Southern Albania).

\section{EXPERIMENTAL}

\section{Plant material}

Salvia officinalis $L$ was collected from Northern and Southern Albania in the month of June, 2011. The specimens were authenticated by Prof H Duman, Department of Biology, Gazi University, Ankara (Turkey). A voucher specimen (no. AEF 26266) was deposited at the Herbarium of the Faculty of Pharmacy of Ankara University in Ankara.

Samples were coded as NAS (northern Albania Sage) and SAS (southern Albania Sage). The plants were kept under refrigerated storage at the facilities of Xherdo Co. Ltd, Albania. The samples were taken randomly from the bulk stored material and leaves were dried, and samples were ready for the distillation process.

\section{Essential oil distillation}

Crushed leaves of the two sage samples (NAS and SAS) were subjected to hydro-distillation for $3 \mathrm{~h}$ in a Clevenger (type) apparatus. The yields of essential oils on a dry weight basis were 3 and $2.3 \%(\mathrm{v} / \mathrm{w})$ for NAS and SAS, respectively. Suspensions of $\sim 1 \mathrm{~g}$ of sage were placed in a $500 \mathrm{~mL}$ round flask together with $100 \mathrm{~mL}$ of distilled water, and $200 \mu \mathrm{L}$ of 2-undecanone $(1000 \mathrm{mg} / \mathrm{L})$ as internal standard. Heating of the sample was continued for $1 \mathrm{~h}$ after getting to the boiling point. The vapours were condensed by means of a cold refrigerant. After $60 \mathrm{~min}$ of extraction, the solvent, $1 \mathrm{~mL}$ of pentane, containing the volatile compounds, was collected in a $2.5 \mathrm{~mL}$ vial and kept at $-18{ }^{\circ} \mathrm{C}$ until GC analyses were performed. The analyses were run in triplicate.

\section{Gas chromatography (GC/FID and GC/MS)}

The isolation, quantification and identification of the volatile components were performed on a gas chromatograph coupled with a mass spectrometry detector (GC/MS), Saturn 2000 Varian Chrompack, with a column TRACE TR-5 (5\% phenyl methylpolysiloxane) $30 \mathrm{~m} \times 0.53$ $\mathrm{mm}$ ID $\times 1.0 \mu \mathrm{m}$ film. Scanning was performed from 39 to $400 \mathrm{~m} / \mathrm{z}$ in electronic impact (EI) at 70 $\mathrm{eV}$, mode at $1 \mathrm{scan} / \mathrm{s}$. Analyses were carried out using helium as carrier gas at a flow rate of 1.0 $\mathrm{mL} / \mathrm{min}$ in a split ratio of 1:20 and the following program: a) $80^{\circ} \mathrm{C}$ for $0 \mathrm{~min}$; b) rate of $5.0^{\circ} \mathrm{C} / \mathrm{min}$ from 80 to $200{ }^{\circ} \mathrm{C}$; c) rate of $25^{\circ} \mathrm{C} / \mathrm{min}$ from 200 to $280{ }^{\circ} \mathrm{C}$ and hold for $5 \mathrm{~min}$. Injector and detector were held at 200 and $300^{\circ} \mathrm{C}$, respectively. The injection volume was $1 \mu \mathrm{L}$. The compounds were identified by using retention indices (RI), and mass spectra, with similarity indexes > $90 \%$ (authentic chemicals and NIST05 spectral library collection; NIST, 2012) [10].

GC/MS was used for identification of the volatile compounds while GC/FID was used for semiquantification of these compounds. The qualitative analysis performed on a gas chromatograph, Shimadzu 2010, with a flame ionization detector (GC/FID). The column and chromatographic conditions were identical to those described in the previous paragraph for the GC/MS analysis. The injector temperature was $200{ }^{\circ} \mathrm{C}$, and nitrogen was used as carrier gas $(1$ $\mathrm{mL} / \mathrm{min}$ ). The semi-quantification was obtained 
from electronic integration measurements. 2Undecanone was added as internal standard $(200 \mu \mathrm{g})$ at the beginning of the distillation procedure to simulate the behavior of all volatile compounds.

\section{MTT assay for determination of cell viability}

The measurement of cell viability of the samples was performed using the MTT (4,5dimethylthiazol-2-yl)-2,5-diphenyl tetrazolium bromide) assay. Briefly, RAW 264.7 cells were plated at a density of $1 \times 10^{4}$ per well in a 96-well plate and incubated at $37^{\circ} \mathrm{C}$ for $24 \mathrm{~h}$. The cells were treated with various concentrations of the oils $(50,100,200$, and $500 \mu \mathrm{g} / \mathrm{mL})$ or vehicle alone. The essential oils were first dissolved in dimethyl sulfoxide (DMSO) to make a $200 \mathrm{mg} / \mathrm{mL}$ stock concentration and further diluted with DMSO for working concentration (shown in Table $1)$. The cell viability was measured according to Khan et al [11,12]. All experiments were performed in triplicate.

\section{Determination of nitric oxide in LPS- stimulated RAW 264.7 Cells}

The NO production of SAS and NAS was evaluated in LPS-stimulated RAW 264.7 cells using the Griess reagent. Briefly, RAW 264.7 cells were plated at a density of $1 \times 10^{5}$ per well in a 24-well plate and incubated at $37{ }^{\circ} \mathrm{C}$ for 24 h. The cells were treated with various concentrations of NAS and SAS or vehicle alone, $2 \mathrm{~h}$ before lipopolysaccharide (LPS) stimulation at $1 \mu \mathrm{g} / \mathrm{mL}$ and incubated at $37{ }^{\circ} \mathrm{C}$ for an additional $18 \mathrm{~h}$ (see Table 2). After incubation for $18 \mathrm{~h}$, NO concentration was determined according to Khan et al [12].

\section{NF-kB SEAP reporter gene assay}

NF-kB-dependent reporter gene transcription was analyzed according to Khan et al [11]. The SEAP assay was used in the determination of the inhibitory activity of the samples in LPS stimulated RAW 264.7 macrophages. In brief, 1 $\times 10^{5}$ RAW 264.7 macrophages transfected with pNF-kB-SEAP-NPT encoding four copies of $-k B$ sequences and the SEAP gene as a reporter was pre-incubated with different concentrations of the oils for $2 \mathrm{~h}$ and challenged with LPS (1 $\mathrm{mg} / \mathrm{mL}$ ) for additional $18 \mathrm{~h}$. Aliquots of the cellfree culture medium were heated at $65^{\circ} \mathrm{C}$ for 5 $\min$ and given an assay buffer [2M diethanolamine, $1 \mathrm{mM} \mathrm{MgCl}_{2}, 500 \mathrm{mM}$ 4methylumbelliferyl phosphate (MUP)] in the dark $37{ }^{\circ} \mathrm{C}$ for $1 \mathrm{~h}$. The fluorescence from the products of the SEAP/MUP was measured using a 96-well microplate fluorometer (Gemini XS,
Molecular Devices) at an excitation of $360 \mathrm{~nm}$ and an emission of $449 \mathrm{~nm}$. In this experiment, $\mathrm{N}$-p-tosyl-L-phenylalanyl chloromethyl ketone (TPCK), $30 \mu \mathrm{M}$, was used as a positive control.

\section{Statistical analysis}

Unless otherwise stated, results are expressed as mean \pm standard deviations (SD) from three different experiments. One-way analysis of variance (ANOVA) followed by Dunnett's t-test was applied to assess the statistical significance for differences between the study groups (SPSS version 10.0, Chicago, IL). A value of $p<0.05$ was chosen as the criterion for statistical significance.

\section{RESULTS AND DISCUSSION}

\section{Volatile composition}

Crushed leaves of Salvia officinalis $L$ collected from Northern and Southern Albania were subjected to hydro-distillation, and the essential oils of sage were analyzed by GC/FID (quantification of volatiles) and GC/MS (identification). $\alpha$-Thujone (30.7 \%), camphor (26.6 \%) and 1, 8-cineole (14.7\%) were found as the major components from the oil from Northern Albania, while camphor (43.8\%), a-thujone (15.9 $\%$ ), camphene $(8.5 \%)$ and 1, 8-cineole (8.4 \%) were the main compounds in the sample from Southern Albania.

In previous studies, the essential oils of some sage populations from Montenegro and Serbia have been studied. In the oil of sage leaves collected from different locations, a-thujone, $\beta$ thujone, borneol and manool were the major components. On the other hand, in Serbian population, camphor was the first major constituents besides thujone and 1, 8-cineole [9]. In another study, the essential oil from the sage dried shoots (vegetative aerial parts) was analyzed by $\mathrm{GC}$, and GC/MS; the major compounds were determined as cis-thujone (17.4\%), a-humulene (13.3\%), 1, 8-cineole $(12.7 \%)$, E-caryophyllene $(8.5 \%)$ and borneol $(8.3 \%)$ [13]. The leaves of $S$. officinalis from Romania have been also analyzed and, $\alpha$ thujone $(21.85 \%)$, camphor (11.25 \%), veridiflorol $(11.71 \%)$ and manool $(9.15 \%)$ were detected as major constituents by GC/MS [7]. The major constituents of the essential oil from aerial parts of $S$. officinalis cultivated in South Brazil were $\alpha$-thujone (24.8\%), 1, 8-cineole (14.8 $\%)$, camphor (10.9\%), borneol (11.1\%) and $\beta$ pinene $(9.87 \%)$ [1]. Moreover, compositions of the essential oils of $S$. officinalis from various European countries were analyzed and $\alpha$ - 
thujone, camphor, $\beta$-thujone and 1,8-cineole were found as major constituents in most of the essential oils under analysis [9].

According to the GC/MS and GC/FID results of the present study, a-thujone (30.7\%), camphor $(26.6 \%)$ and 1,8 -cineole $(14.7 \%)$ were the major components of the essential oils of the sage samples from Northern Albania (NAS). The main constituents of the essential oil of NAS are presented in Table 1, and a model chromatogram of the NAS samples is shown in Figure 1. However, the essential oil of the
Southern Albania sage (SAS) was dominated by camphor (43.8\%), a-thujone (15.9\%), camphene $(8.5 \%)$ and 1,8 -cineole $(8.4 \%)$ as presented in Table 4; a model chromatogram of the SAS samples is shown in Figure 2. As some papers have previously reported, the variation in the essential oil composition is influenced by environmental (climatic, seasonal, and geographical), physiological and morphological factors $[1,9]$. Finally, it can be considered that the NAS sample could be classified as $\alpha$-thujone chemotype, while SAS sample could be considered as a camphor chemotype.

Table 1: Essential oil composition of Salvia officinalis L. from northern (NAS) and southern (SAS) Albania

\begin{tabular}{|c|c|c|c|c|c|}
\hline \multirow{2}{*}{ Peak no. } & \multicolumn{2}{|c|}{ Retention index } & \multirow{2}{*}{ Compound } & \multirow{2}{*}{\multicolumn{2}{|c|}{$\begin{array}{c}\text { NAS } \\
\text { Area (\%) }\end{array}$}} \\
\hline & Experimental & Literature $^{\dagger}$ & & & \\
\hline 1 & 859 & 867 & cis-Salvene & 0.39 & 0.22 \\
\hline 2 & 862 & 855 & trans-2-Hexenal & 0.02 & 0.01 \\
\hline 3 & 875 & 880 & trans-Salvene & 0.06 & 0.04 \\
\hline 4 & 937 & 928 & a-Thujene & 0.13 & 0.16 \\
\hline 5 & 938 & 931 & Tricyclene & 0.09 & 0.23 \\
\hline 6 & 945 & 939 & $\alpha$-Pinene & 2.02 & 2.32 \\
\hline 7 & 960 & 953 & Camphene & 4.15 & 8.49 \\
\hline 8 & 975 & 976 & Sabinene & 0.03 & 0.06 \\
\hline 9 & 996 & 990 & $\beta$-Pinene & 2.73 & 2.36 \\
\hline 10 & 1011 & 1005 & $\alpha$-Phelandrene & 0.10 & 0.10 \\
\hline 11 & 1023 & 1018 & $\alpha$-Terpinene & 0.34 & 0.26 \\
\hline 12 & 1029 & 1026 & p-Cymene & 0.28 & 0.26 \\
\hline 13 & 1033 & 1031 & Limonene & 2.69 & 3.77 \\
\hline 14 & 1038 & 1035 & 1,8-Cineole & 14.73 & 8.35 \\
\hline 15 & 1057 & 1062 & $y$-Terpinene & 0.61 & 0.47 \\
\hline 16 & 1087 & 1088 & Terpinolene & 0.57 & 0.80 \\
\hline 17 & 1110 & 1102 & $\alpha$-Thujone & 30.72 & 15.92 \\
\hline 18 & 1119 & 1114 & $\beta$-Thujone & 5.38 & 1.71 \\
\hline 19 & 1152 & 1143 & Camphor & 26.57 & 43.83 \\
\hline 20 & 1186 & 1182 & Terpinen-4-ol & 0.64 & 0.48 \\
\hline nd-21 & 1200 & 1197 & $\alpha$-Terpineol & nd & 0.43 \\
\hline 21-22 & 1278 & 1285 & Bornyl acetate & 3.15 & 5.59 \\
\hline $22-23$ & 1418 & 1419 & trans- $\beta$-Caryophyllene & 2.00 & 1.58 \\
\hline $23-24$ & 1453 & 1454 & $\alpha$-Humulene & 2.60 & 2.56 \\
\hline
\end{tabular}

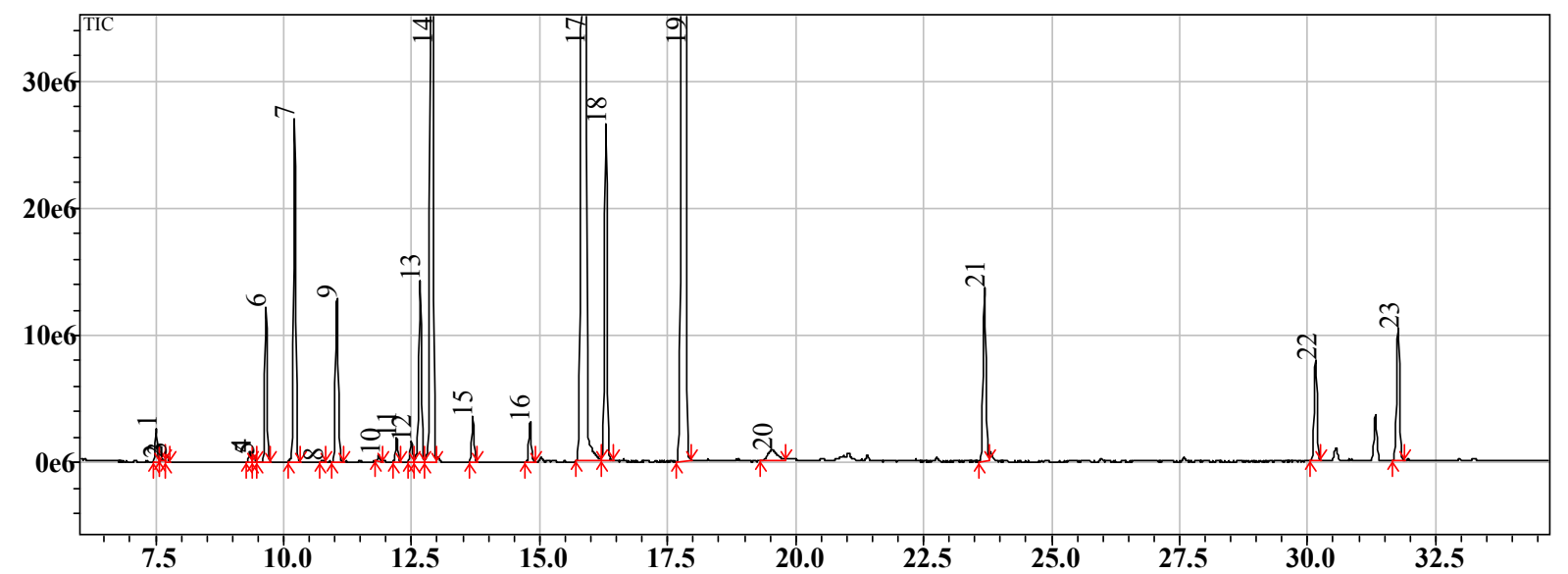

Figure 1: Model GC/MS chromatogram of Salvia officinalis from the northern Albania sample (NAS) 


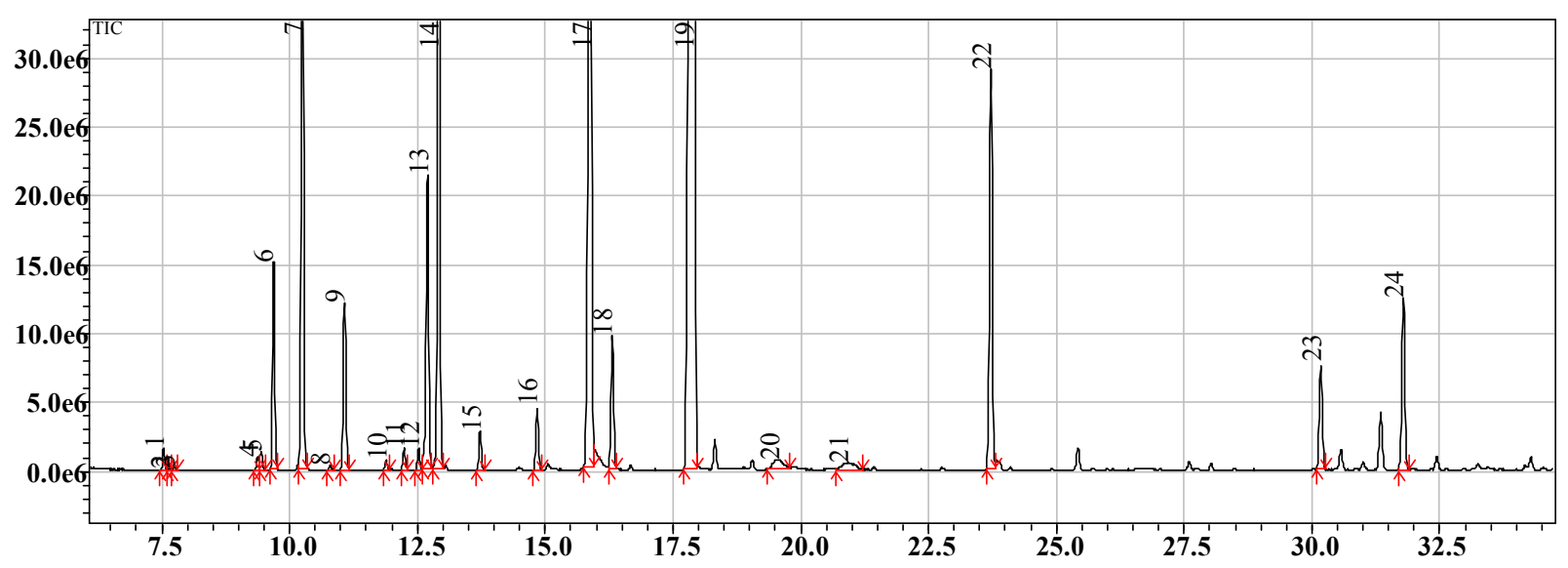

Figure 2: Model GC/MS chromatogram of Salvia officinalis from the southern Albania sample (SAS)

\section{Cell viability}

To explore the principle mechanism underlying this anti-inflammatory effect, the action of NAS and SAS on inflammation related macrophage functions was evaluated. The cytotoxic effect of SAS and NAS in LPS-stimulated RAW 264.7 macrophages was measured using a MTT assay and results are shown in Table 2. No cytotoxic effect was observed up to $500 \mu \mathrm{g} / \mathrm{ml}$ in SAS and $200 \mu \mathrm{g} / \mathrm{mL}$ in NAS, respectively. It is apparent that non-toxic concentrations were used in the onward experiments.

Table 2: Effect of NAS and SAS on cell viability in LPS-stimulated RAW 264.7 cells

\begin{tabular}{|c|c|c|c|c|c|}
\hline \multirow[b]{2}{*}{ Sample } & \multicolumn{4}{|c|}{$\begin{array}{l}\text { Essential oil concentration } \\
(\mu \mathrm{g} / \mathrm{mL})\end{array}$} & \multirow{2}{*}{$\begin{array}{c}I_{50} \\
(\mu \mathrm{g} / \mathrm{mL})\end{array}$} \\
\hline & 50 & 100 & 200 & 500 & \\
\hline & \multicolumn{4}{|c|}{ MTT (\% inhibition) } & \\
\hline $\begin{array}{l}\text { NAS } \\
\text { SAS }\end{array}$ & $\begin{array}{l}7.46 \\
4.30\end{array}$ & $\begin{array}{l}14.24 \\
13.92\end{array}$ & $\begin{array}{l}16.16 \\
13.30\end{array}$ & $\begin{array}{l}60.1^{*} \\
20.56\end{array}$ & $\begin{array}{l}>200 \\
>500\end{array}$ \\
\hline
\end{tabular}

NAS and SAS mean northern and southern Albania samples, respectively. The data were obtained from three independent experiments and expressed as mean $\pm S D$; * $p<0.05$ indicate significant difference from the LPS-stimulated RAW 264.7 cells

\section{Nitric oxide production}

Nitric oxide (NO) is an important proinflammatory mediator and responsible for various inflammatory responses. Therefore, the suppression of NO production can be essential to the development of anti-inflammatory agents. In the current study, it was found that NAS and SAS significantly inhibited LPS-induced NO production in RAW 264.7 cells. Pre-treatment with NAS and SAS considerably inhibited LPSinduced NO production (Table 3 ). No cytotoxic effect was observed in the tested concentrations of NAS and SAS. Hence, experimental data suggested that reducing NO production by NAS and SAS was not due to a toxic reaction of the cells. AMT (2-amino-5, 6-dihydro-6- methyl-4H-1, 3-thiazine), $10 \mu \mathrm{M}$, was used as positive control.

Table 3: Effect of NAS and SAS on nitrite production in LPS-stimulated RAW 264.7 cells

\begin{tabular}{|c|c|c|c|c|c|}
\hline \multirow{3}{*}{ Sample } & \multicolumn{4}{|c|}{ Essential oil concentration $(\mu \mathrm{g} / \mathrm{mL})$} & \multirow{3}{*}{$\begin{array}{c}\mathrm{IC}_{50} \\
(\mu \mathrm{g} / \mathrm{mL})\end{array}$} \\
\hline & 50 & 100 & 200 & 500 & \\
\hline & \multicolumn{4}{|c|}{ Nitrite (\% inhibition) } & \\
\hline NAS & $12.16^{*}$ & $60.61^{* * *}$ & $70.92^{\star * *}$ & $91.13^{* * *}$ & 105.1 \\
\hline SAS & - & $35.25^{\star *}$ & $46.18^{* \star *}$ & $90.30^{* * *}$ & 191.1 \\
\hline
\end{tabular}

NAS and SAS mean northern and southern Albania samples, respectively. The data were obtained from three independent experiments and expressed as mean $\pm S D ;{ }^{*} p<0.05,{ }^{* *} p<0.01$, and ${ }^{* * *} p<0.001$ indicate significant difference from the LPS-stimulated RAW 264.7 cells

\section{NF-KB transcription factor}

NF-KB transcription factor has been evidenced to play a significant role in LPS-induced expression of pro-inflammatory mediators, including $\mathrm{NO}$ and $\mathrm{PGE}_{2}$ [11]. In order to investigate the molecular mechanism of these essential oils mediated inhibition of $\mathrm{NO}$ and $\mathrm{PGE}_{2}$, NF-kB transcription activity was measured using the reporter gene assay. RAW 264.7 cells were stably transfected with NF-KB-SEAP-NPT plasmid containing four copies of $K B$ sequence fused to SEAP as the reporter [12]. LPS treatment of the transfected cells for $18 \mathrm{~h}$ increased the SEAP expression (Table 4). Pretreatment with SAS and NAS significantly inhibited LPS-induced SEAP expression in a concentration-dependent manner; the maximum inhibition at $500 \mu \mathrm{g}$ 
$\mathrm{SAS} / \mathrm{mL}$ at and $200 \mu \mathrm{g} \mathrm{NAS} / \mathrm{mL}$, respectively (Table 4). As a positive control, TPCK also showed a significant inhibitory effect on NF-KB activation at the transcription level.

Table 4: Effect of NAS and SAS on NF-KB in LPSstimulated RAW 264.7 cells

\begin{tabular}{|c|c|c|c|c|c|}
\hline \multirow{3}{*}{ Sample } & \multicolumn{4}{|c|}{ Essential oil concentration $(\mu \mathrm{g} / \mathrm{mL})$} & \multirow{2}{*}{$\begin{array}{c}\mathrm{IC}_{50} \\
(\mu \mathrm{g} / \mathrm{mL})\end{array}$} \\
\hline & 50 & 100 & 200 & 500 & \\
\hline & \multicolumn{4}{|c|}{ NF-KB SEAP (\% inhibition) } & \\
\hline NAS & $48.40^{\star * *}$ & $68.33^{* * *}$ & $68.53^{\star \star *}$ & - & 44.5 \\
\hline SAS & $35.65^{*}$ & $43.39^{\star *}$ & $67.01^{* * *}$ & $82.10^{\star * *}$ & 107.5 \\
\hline
\end{tabular}

NAS and SAS mean northern and southern Albania samples, respectively. The data were obtained from three independent experiments and expressed as mean $\pm S D ;{ }^{*} p<0.05,{ }^{* *} p<0.01$ and ${ }^{* * *} p<0.001$ indicate significant difference from the LPS-stimulated RAW 264.7 cells

In order to link all data generated in this study, it can be stated that the essential oil of SAS (southern Albania sage) led to higher cell viability (Table 2), lower inhibition percentages of nitric oxide production (Table 3 ) and also lower inhibition of NF-KB transcription activity (Table 4) than NAS (northern Albania sage). The volatile compositions of SAS and NAS led to the classification of these sage samples as camphor and $\alpha$-thujone chemotypes according to the predominant volatile compound. Therefore, our recommendation is to use camphor chemotypes of sage (e.g. SAS) in medicinal treatments due to their higher anti-inflammatory activity.

\section{CONCLUSION}

Therefore, while NAS samples have $\alpha$-thujone $(30.17 \%)$ as the most abundant constituent, camphor $(43.8 \%)$ was predominant in SAS samples. However, it is obvious that the content of $\alpha$ - and $\beta$-thujone and camphor are effective for determining the quality of sage oil quality. This is important since the high quality of the oil are due to their contents of thujone and camphor, and because the biological properties of sage oil are mainly attributable to camphor, 1, 8-cineole and $\alpha$ - and $\beta$-thujone. Furthermore, the essential oils of Albanian sage possess significant antiinflammatory but the chemotypes with camphor predominating are highly recommended.

\section{REFERENCES}

1. Longaray Delamare AP, Moschen-Pistorello IT, Artico L, Atti-Serafini L, Echeverrigaray S. Antibacterial activity of the essential oils of Salvia officinalis L. and Salvia triloba L. cultivated in South Brazil. Food Chem, 2007; 100: 603-608.

2. Capek $P$, Hribalová $V$, Švandová $E$, Ebringerová $A$, Sasinková V, Masarová J. Characterization of immunomodulatory polysaccharides from Salvia officinalis L. Int J Biol Macromol, 2003; 33: 113-119.

3. Mayer $B$, Baggio $\mathrm{CH}$, Freitas CS, Santos AC, Twardowschy A, Horst $H$, Pizzolatti MG, Micke GA, Heller M, Santos ÉP, FleithOtuki M, Marques MCA. Gastroprotective constituents of Salvia officinalis $L$. Fitoterapia 2009; 80: 421-426.

4. Baricevic $D$, Sosa $S$, Della Loggia $R$, Tubaro $A$, Simonovska B, Krasna A, Zupancic A. Topical antiinflammatory activity of Salvia officinalis L. leaves: the relevance of ursolic acid. J Ethnopharmacol, 2001; 75: 125-132.

5. Lu Y, Foo LY. Antioxidant activities of polyphenols from sage (Salvia officinalis). Food Chem, 2001; 75: 197202.

6. Kamatou GPP, Makunga NP, Ramogola WPN, Viljoen AM. South African Salvia species: A review of biological activities and phytochemistry. J Ethnopharmacol, 2008; 119: 664-672.

7. Radulescu V, Chiliment S, Oprea E. Capillary gas chromatography-mass spectrometry of volatile and semi-volatile compounds of Salvia officinalis. J. Chromatogr A, 2004; 1027: 121-126.

8. Miura K, Kikuzaki H, Nakatani N. Apianane terpenoids from Salvia officinalis. Phytochemistry 2001; 58: 1171-1175.

9. Raal A, Orav A, Arak E. Composition of the essential oil of Salvia officinalis $L$. from various European countries. Nat Prod Res, 2007; 21: 406-411.

10. NIST (National Institute of Standards and Technology, 2012). http://webbook.nist.gov/chemistry/nameser.html [accessed August 2012].

11. Khan S, Shin EM, Choi RJ, Jung YH, Kim J, Tosun A, Kim YS. Suppression of LPS-induced inflammatory and NF-kB responses by anomalin in RAW 264.7 macrophages. J Cell Biochem 2011; 112: 2179-2188.

12. Khan S, Shehzad O, Jin HG, Woo ER, Kang SS, Baek SW, Kim J, Y.S. Kim. Anti-inflammatory mechanism of 15,16-epoxy-3a-hydroxylabda-8,13(16), 14-trien-7one via inhibition of LPS-induced multicellular signaling pathways. J Nat Prod. 2012; 75: 67-71.

13. Lima CF, Carvalho F, Fernandes E, Bastos ML, SantosGomes PC, Fernandes-Ferreira M, Pereira-Wilson C. Toxicology in vitro 2004; 18: 457-465. 